\title{
PENERAPAN MODEL PEMBELAJARAN EXAMPLE NON EXAMPLES UNTUK MENINGKATKAN HASIL BELAJAR IPS
}

\author{
Feri Poko ${ }^{1, *}$ \\ 1 Universitas Pendidikan Ganesha
}

\begin{abstract}
Abstrak
Penelitian tindakan kelas ini bertujuan untuk meningkatkan hasil belajar IPS siswa melalui penerapan model pembelajaranexamples non examplesdi kelas IV SD Negeri4KaliuntuSemester I TahunPelajaran 2017/2018.Subjek dalam penelitian ini adalah siswa kelas IV SD Negeri 4 Kaliuntu yang berjumlah 33 orang terdiri dari 12 siswa perempuan dan 21 siswa laki-laki. Metode pengumpulan data yang digunakan dalam penelitian ini adalah metode tes. Instrumen pengumpulan data hasil belajar yang digunakan adalah tes objektif pilihan ganda biasa. Data dianalisis dengan menggunakan metode analisis statistik deskriptif dan metode analisis deskriptif kuantitatif. Hasil penelitian ini menunjukkan bahwa terjadi peningkatan hasil belajar sebesar 0,21 dari prasiklus ke siklus I, sebesar 0,39 dari siklus I ke siklus II. Peningkatan hasil belajar IPS siswa dari prasiklus ke siklus II sebesar 0,52. Rata-rata peningkatan nilai hasil IPS siswa dari prasiklus hingga siklus II sebesar 0,3 yang tergolong pada kategori sedang. Sehingga tujuan penelitian ini tercapai bahwa penerapan model Examples Non Examples dapat meningkatkan hasil belajar siswa.
\end{abstract}

\author{
Keywords: \\ Examples Non Examples \\ dan Hasil Belajar
}

\section{Pendahuluan}

Pendidikan merupakan sumber kemajuan bangsa yang sangat menentukan daya saing bangsa. Dalam Undang-undang Sistem Pendidikan Nasional Nomor 20 Tahun 2003 pasal 3 disebutkan bahwa Pendidikan nasional berfungsi untuk mengembangkan kemampuan dan membentuk watak serta peradaban bangsa yang bermartabat dalam rangka mencerdaskan kehidupan bangsa, bertujuan untuk berkembangnya potensi peserta didik agar menjadi manusia yang beriman dan bertakwa kepada Tuhan Yang Maha Esa, berakhlak mulia, sehat, berilmu, cakap, kreatif, mandiri, dan menjadi warga negara yang demokratis serta bertanggung jawab.

Peningkatan mutu pembelajaran sangat perlu dilakukan guna meningkatkan kompetensi peserta didik sebagai calon sumber daya manusia yang berkualitas, terutama pembelajaran di Sekolah Dasar, karena pendidikan di Sekolah Dasar merupakan jenjang pendidikan dasar yang berfungsi sebagai peletakan dasar-dasar keilmuan dan membantu mengoptimalkan perkembangan siswa melalui pembelajaran yang dibimbing oleh guru.

Berdasarkan Standar Kompetensi dan Kompetensi Dasar Tingkat SD/MI dalam Peraturan Menteri Pendidikan Nasional Nomor 22 Tahun 2006 tentang Standar Isi untuk satuan pendidikan dasar dan menengah bahwa standar kompetensi IPS adalah ilmu yang mengkaji seperangkat peristiwa, fakta, konsep, dan generalisasi yang berkaitan dengan isu sosial. Dengan kompetensi tersebut maka peserta didik diarahkan untuk dapat menjadi warga negara Indonesia yang demokratis, dan bertanggung jawab, serta warga dunia yang cinta damai. Mata pelajaran IPS dirancang untuk mengembangkan pengetahuan, pemahaman, dan kemampuan analisis terhadap kondisi sosial masyarakat dalam memasuki kehidupan bermasyarakat yang dinamis.

Berkaitan dengan hal itu, pengajaran IPS di sekolah dasar harus memungkinkan siswa untuk memahami dan menemukan suatu konsepnya sendiri, memotivasi siswa untuk belajar secara aktif serta meningkatkan hasil belajar siswa yang cukup signifikan. Untuk mencapai target tersebut maka perlu adanya penerapan model yang efektif yang tidak mengharuskan siswa untuk menghafal fakta-fakta dalam 
IPS tetapi dengan adanya suatu model yang mendorong siswa untuk belajar menemukan konsep secara mandiri dengan adanya bimbingan dari pendidik.

Realita yang terjadi saat membelajarkan IPS, guru yang hanya berceramah di depan kelas dengan menjelaskan materi pelajaran yang kompleks tanpa menggunakan media pembelajaran. Hal ini mengakibatkan guru kurang dapat memberikan deskripsi yang jelas mengenai materi yang diajarkan sehingga siswa menjadi kurang termotivasi untuk mengikuti proses pembelajaran.

Demikian pula dalam menerapkan model pembelajaran, seringkali guru memaksakan suatu model tertentu untuk membelajarkan materi yang sebenarnya kurang tepat dan bahkan mungkin tidak sesuai sama sekali. Hal inilah membutuhkan kejelian seorang guru untuk memilih dan menentukan model yang tepat dengan materi yang dibelajarkan karena pada dasarnya model adalah cara yang sistematis untuk mempermudah siswa memahami materi pembelajaran.

Berdasarkan observasi yang telah dilakukan di SD Negeri 4 Kaliuntu Kecamatan Buleleng Kabupaten Buleleng terungkap, ketika melaksanakan proses pembelajaran IPS kompetensi dasar tentang sumber daya alam yang dapat diperbaharui dan sumber daya alam yang tidak dapat diperbaharui pada siswa kelas IV semester I di SD Negeri 4 Kaliutu, Kecamatan Buleleng, Kabupaten Buleleng menunjukkan hasil yang kurang memuaskan. Hal ini ditunjukkan dari hasil tes formatif, yakni dari 33 siswa yang memperoleh nilai tuntas atau nilai $\geq$ KKM (65) hanya 16 orang atau tingkat tuntas klasikal hanya 48\%. Dengan demikian pembelajaran pada kompetensi dasar tersebut tidak berhasil karena pembelajaran dikatakan berhasil jika kriteria keberhasilan mencapai $\geq 60 \%$. Dari perolehan nilai tersebut menunjukkan bahwa penguasaan materi belum tuntas. Hal ini, dikarenakan, perhatian siswa terhadap materi yang disampaikan guru masih kurang, dimana guru jarang menggunakan media yang menarik sehingga siswa di kelas IV SD Negeri 4 Kaliuntu cepat bosan, partisipasi siswa dalam proses pembelajaran masih kurang. masih banyak siswa yang berbicara sendiri dengan temannya saat berlangsungnya proses pembelajaran

Berdasarkan temuan masalah tersebut, maka perlu diberikan suatu usaha penanganan masalah. Penanganan yang dilakuakan yaitu dengan menggunakan model pembelajaran inovatif examples non examples. Peneliti menggunakan model examples non examples dengan alasan, model ini dapat melibatkan siswa untuk dapat aktif dalam kegiatan pembelajaran.

Kelebihan Model Pembelajaran Examples non Examples (Depdiknas, 2007:219) mengemukakan keuntungan model pembelajaran, sebagai berikut: Siswa berangkat dari satu definisi yang selanjutnya digunakan untuk memperluas pemahaman konsepnya dengan lebih mendalam dan lebih komplek. Siswa terlibat dalam satu proses discovery (penemuan), yang mendorong mereka untuk membangun konsep secara progresif melalui pengalaman dari exaples non examples. Siswa diberi sesuatu yang berlawanan untuk mengeksplorasi karakteristik dari suatu konsep dengan mempertimbangkan bagian non examples yang dimungkinkan masih terdapat beberapa bagian yang merupakan suatu karakter dari konsep yang telah dipaparkan pada bagian examples. Langkah - langkah Penerapan Pembelajaran Examples non Examples. Menurut Komalasari (2010:61) langkah-langkah penerapan pembelajaran example non example adalah sebagai berikut. a).Guru mempersiapkan gambar-gambar sesuai dengan tujuan pembelajaran.b) Guru menempelkan gambar di papan atau ditayangkan lewat LCD. c) Guru memberi petunjuk dan memberi kesempatan kepada siswa untuk memperhatikan / menganalisa gambar. d) Melalui diskusi kelompok 2-4 orang siswa, hasil diskusi dari analisa gambar tersebut dicatat pada kertas. e) Tiap kelompok diberi kesempatan membacakan hasil diskusinya. f) Mulai dari komentar / hasil diskusi siswa, guru mulai menjelaskan materi sesuai tujuan yang ingin dicapai. g) Kesimpulan

Berdasarkan latar belakang masalah tersebut, maka peneliti perlu melakukan suatu tindakan. Tindakan yang dilakukan berupa penelitian dengan judul "Penerapan Model Pembelajaran Examples Non Examples untuk Meningkatkan Hasil Belajar IPS Siswa Kelas IV di SD Negeri 4 Kaliuntu Semester I Tahun Pelajaran 2017/2018.

Rumusan masalah dalam penelitian ini adalah "Apakah melalui penerapan model pembelajaran examples non examples dapat meningkatkan hasil belajar IPS siswa kelas IV SD Negeri 4 Kaliuntu Tahun Pembelajaran 2017/2018?. Berdasarkan rumusan masalah diatas, penulis tertarik meneliti apakah model pembelajaran examples non examples dapat meningkatkan hasil belajar siswa. Menurut Pasaribu (1983:91) hasil belajar merupakan kapasitas seseorang atau hasil yang diperoleh seseorang setelah mengikuti pendidikan atau pelatihan yang dapat diukur menggunakan tes pada akhir pendidikan itu. IPS merupakan salah satu mata pelajaran yang sangat penting dalam kurikulum sekolah dasar, pendidikan IPS memiliki tujuan jelas yaitu meningkatkan sumber daya manusia seutuhnya yang memiliki keterampilan sosial serta mampu menghadapi tantangan yang dialami dikehidupannya, mampu menghadapi tantangan yang dialami dalam kehidupannya, serta mampu menghargai dan memecahkan masalah-masalah dalam konflik sosial sebagai makhluk sosial dan mahluk Tuhan Yang Maha Esa. Agus Suprijono (2009:46) mengemukakan, bahwa: model pembelajaran merupakan pola yang digunakan sebagai pedoman dalam merencanakan pembelajaran dikelas maupun tutorial. Model pembelajaran 
merupakan bentuk pembelajaran yang tergambar dari awal sampai akhir yang disajikan dikelas pada kegiatan pembelajaran.

Menurut Afrisanti Lusia (2008:83) model pembelajaran examples non examples adalah model mengajar dengan menggunakan contoh-contoh. Contoh-contoh dapat dari kasus-kasus atau gambar yang relevan. Model pembelajaran examples non examples merupakan model pembelajaran yang menggunakan gambar sebagai media pembelajaran. Penggunaan media gambar ini dirancang dan disusun agar anak dapat menganalisis gambar tersebut menjadi sebuah diskripsi singkat mengenai apa yang ada didalam gambar. Penggunaan model examples non examples ini lebih menekankan pada konteks analisis siswa. Model pembelajaran examples non examples menggunakan gambar dapat melalui OHP, proyektor, ataupun yang paling sederhana adalah poster. Gambar yang kita gunakan haruslah jelas dan kelihatan dari jarak jauh, sehingga anak yang berada dibelakang dapat jugamelihat dengan jelas. Examples non examples adalah taktik yang dapat digunakan untuk mengajarkan definisi konsep taktik ini bertujuan untuk mempersiapkan siswa secara cepat dengan menggunakan dua hal yang terdiri dari examples dan non examples dari suatu definisi yang ada, dan meminta siswa untuk mengklasifikasikan keduanya sesuai dengan konsep yang ada. Examples memberikan gambaran akan sesuatu yang menjadi contoh akan suatu materi yang sedang dibahas, sedangkan non examples memberikan gambaran akan sesuatu yang bukanlah contoh dari suatu materi yang sedang dibahas. Berdasarkan penjelasan mengenai pengertian model pembelajaran examples non examples, dapat disimpulkan bahwa model pembelajaran examples non examples adalah model pembelajaran dengan menggunakan media gambar untuk dianalisis oleh siswa dan menghasilkan diskripsi singkat dari suatu materi pelajaran menekankan kemampuan siswanya untuk menganalisis sebuah konsep dengan contoh dan non contoh yaitu dari contoh materi yang dibahas bukan contoh dari materi yang dibahas.

\section{Metode}

Penelitian ini dilaksanakan selama empat bulan yaitu bulan Juli-Oktober pada Semester I Tahun Ajaran 2017/2018 dengan mengambil tempat di SD N 4 Kaliuntu.Subjek penelitian ini adalah siswa kelas IV SD N 4 Kaliuntu Semester I Tahun 2017/2018. Jumlah siswa kelas IV SD N 4 Kalintu adalah 33 orang, yang terdiri dari 12 orang perempuan dan 21 orang laki-laki.

Penelitian ini mengikuti tahap-tahap penelitian tindakan kelas sebagaimana dikemukakan Kemmis dan Taggart (dalam Agung, 2005:91) yang masing-masing siklus terdiri atas empat tahap yaitu: (1) perencanaan tindakan, (2) pelaksanaan tindakan, (3) observasi atau evaluasi, serta (4) refleksi.Siklus pada penelitian ini dilaksanakanya sampai tercapainya indikator keberhasilan yang telah ditetapkan. Tiap siklus terdiri dari empat tahapan yaitu: perencanaan, pelaksanaan/tindakan, observasi/evaluasi dan refleksi (Agung, 2005).

Terdapat satu variabel terikat yang menjadi fokus perhatian dalam penelitian ini yaitu prestasi belajar IPS setelah penerapan model pembelajaran examples dan non examples. Prestasi belajar IPS merupakan hasil belajar siswa ranah kognitif pada muatan IPS, diukur dengan menggunakan indikator yang telah dirumuskan dari kompetensi dasar yang telah ditentukan. Untuk mengukur prestasi belajar pengetahuan IPS menggunakan tes objektif dan data yang dihasilkan bersifat interval (skor).

Data hasil belajar IPS siswa dikumpulkan dengan metode tes setelah proses pembelajaran. Metode tes adalah cara memperoleh data yang berbentuk suatu tugas yang harus dikerjakan oleh seseorang atau kelompok orang yang dites.Tes dalam penelitian ini digunakan untuk mengukur hasil belajar siswa pada muatan IPS kelas IV semester I Tahun Pelajaran 2017/2018 di SD N 4 Kaliuntu setelah penerapan model pembelajaran examples non examples dalam proses pembelajaran. Tes tersebut berupa butir-butir soal sesuai dengan materi pembelajaran. Agar butir-butir soal dapat mengukur tujuan pembelajaran yang diharapkan maka perlu dibuatkan kisi-kisi soal. Instrumen yang digunakan untuk mengukur hasil belajar siswa adalah perangkat tes pilihan ganda.

Metode analisis data yang digunakan adalah metode analisis statistik deskriptif. Metode analisis statistik deskriptif ialah suatu cara pengolahan data yang dilakukan dengan jalan menerapkan rumusrumus statistik deskriptif seperti: distribusi frekuensi, grafik, angka rata-rata (Mean), median (Me), dan modus (Mo) untuk menggambarkan keadaan suatu objek tertentu sehingga diperoleh kesimpulan umum (Agung, 2005:60).Penerapan metode analisis statistik deskriptif dalam penelitian ini, data yang diperoleh dari hasil penelitian dianalisis dan disajikan ke dalam: a) tabel distribusi frekuensi, b) menghitung modus, c) menghitung median, d) menghitung angka rata-rata, dan e) menyajikan data.

Peningkatan hasil belajar siswa mata pelajaran IPS ditentukan dengan membandingkan nilai yang diperoleh pada prasiklus, siklus I, siklus II dan seterusnya.Penelitian ini berhasil apabila kriteria keberhasilan prestasi belajar IPS mencapai kategori sedang $(\mathrm{G}=0,3 \mathrm{sd} 0,7)$, dengan demikian penelitian 
dapat diakhiri. Apabila kategori yang dicapai rendah $(\mathrm{G}<0,3)$, maka dilanjutkan kesiklus selanjutnya sampai tercapai indikator yang ditentukan.

\section{Hasil dan Pembahasan}

Model examples dan non examples membantu siswa dalam memahami materi pelajaran karena dibantu dengan gambar-gambar menarik yang membuat siswa menjadi lebih mudah mengingat materi pelajaran. Dalam langkah-langkahnya sangat berpengaruh mengembangkan pengetahuan siswa. Pada langkah memberi gambar atau foto untuk ide siswa dapat mengembangkan C2 kemampuan kognitif 2 pada siswa karena gamabar-gambar akan lebih menarik, membuat kita tetap terfokus, membantu kita berkonsentrasi, dan mengaktifkan otak kita. Memberi berbagai gambar dapat membantu mengembangkan C2 dan C3, karena bagi otak menariknya dengan gambar. Pembelajaran examples non examples ini telah menekankan pada konteks analisis siswa. Biasanya model ini lebih dominan digunakan di kelas tinggi, namun dapat juga digunakan di kelas rendah dengan menekankan aspek psikologis dan tingkat perkembangan siswa kelas rendah seperti: (a) kemampuan berbahasa tulis dan lisan; (b) kemampuan analisis ringan, dan (c) kemampuan berinteraksi dengan siswa bekerja dalam kelompokkelompok kecil, saling membantu belajar satu sama lainnya dengan beranggotakan 4-6 siswa atau lebih. Jadi model pembelajaran examples non examples dapat membantu meningkatkan pengetahuan siswa dengan dibuktikan data berikut ini.

Data awal menunjukkan hasil belajar IPS siswa sebesar 48,7\% tergolong pada kategori rendah. hasil belajar IPS siklus I mengalami peningkatan menjadi $72,66 \%$ termasuk dalam kategori sedang dan meningkat kembali pada siklus II menjadi 83,45\% menunjukkan hasil belajar IPS siswa pada kategori tinggi. Peningkatan hasil terjadi karena adanya kerjasama, kreatifitas dan pemahaman yang dimiliki siswa dalam menempelkan gambar sesuai materi. Anak dapat menyajikan materi dengan menarik sehingga memberikan semangat belajar dan belajar bermakna.

Walaupun telah diadakan perbaikan pembelajaran yang mengacu pada kelemahan di siklus I, hasil menempel gambar sesuai materi yang diajarkan kepada anak belum mencapai maksimal yaitu sangat tinggi. Anak belum terbiasa melakukan kegiatan pembelajaran dengan menggunakan model

pembelajaran model Examples Non Examples. Adanya belum keterbiasaan ini, tentu materi yang disajikan lebih fokus pada estitika bukan pada materi.

Hasil analisis data menunjukkan bahwa terjadi peningkatan hasil belajar sebesar 0,21 dari prasiklus ke siklus I, sebesar 0,39 dari siklus I ke siklus II. Peningkatanhasil belajar IPS siswa dari prasiklus ke siklus II sebesar 0,52. Rata-rata peningkatan nilai hasil menempel gambar siswa dari prasiklus hingga siklus II sebesar 0,3 yang tergolong pada kategori sedang. Sehingga tujuan penelitian ini tercapai bahwa penerapan model pembelajaran model Examples Non Examplesdapat meningkatkan prestasi siswa.

Hasil belajar IPS siswa dapat menunjukkan prestasi (nilai) yang mereka peroleh selama pada evaluasi akhir pembelajaran. Mengingat model Examples Non Examplesadalah salah satu model pembelajaran yang memberikan kegiatan yang bermakna. Untuk itulah model Examples Non Examplesadalah cara termudah untuk menempatkan informasi ke dalam otak dan mengambil informasi ke luar dari otak, selain itu model Examples Non Examplesmerupakan salah satu cara mencatat kreatif, efektif dan secara harfiah akan "memetakan" pikiran-pikiran kita (Buzan 2008:14).

Hal ini menunjukkan bahwa sesuai dengan teori-teori yang ada, penerapan model ini telah berhasil meningkatkan prestasi belajar IPS siswa yang ditandai perolehan nilai semua siswa atau $90 \%$ berhasil melewati nilai minimal yang disyaratkan yaitu 65 .

\section{Simpulan}

Berdasarkan hasil analisis sebagaimana disajikan dalam Bab IV, maka dapat disimpulkan bahwa penerapan penerapan model pembelajaran model Examples Non Examples dapat meningkatkan hasil belajar IPS Siswa Kelas V Semester I Tahun Pelajaran 2017/2018 di SD Negeri 4 Kaliuntu. Berdasarkan data awal hasil belajar IPS siswa sebesar 65,7\% tergolong pada kategori rendah. Hasil belajar IPS siklus I mengalami peningkatan menjadi $72,66 \%$ termasuk dalam kategori sedang dan meningkat kembali pada siklus II menjadi 83,45\% menunjukkan hasil belajar IPS siswa pada kategori tinggi. Jadi terjadi peningkatan hasil belajar sebesar 0,21 dari prasiklus ke siklus I, sebesar 0,39 dari siklus I ke siklus II. Peningkatan hasil belajar IPS siswa dari prasiklus ke siklus II sebesar 0,52. Rata-rata peningkatan nilai hasil menggambar siswa dari prasiklus hingga siklus II sebesar 0,3 yang tergolong pada kategori 
sedang. Sehingga tujuan penelitian ini tercapai bahwa penerapan model pembelajaran model Examples Non Examples dapat meningkatkan hasil siswa.

\section{Daftar Pustaka}

Agung, A. A. G. 2005. Metodologi Penelitian Pendidikan. Singaraja: Fakultas Ilmu Pendidikan Institut Keguruan dan Keilmuan Negeri Singaraja.

-----. 2010. Metodologi Penelitian Pendidikan. Singaraja: FIP Undiksha.

Ahmadi dan Supriyono. 2004. Psikologi Belajar. Jakarta: Rineka Cipta

Ahmadi, dkk., 2005. Strategi Belajar Mengajar. Bandung: CV. Pustaka Setia

Andriani, J. 2013. Definisi Strategi Pembelajaran, Model, Model, Pendekatan, Teknik Menurut Para Ahli, Kendari, Sulawesi Tenggara, Indonesia (http://andriani-jafar.blogspot. com/2012/03/definisistrategi-pembelajaran-model.html) di akses pada tanggal 12 juli 2017

Arikunto. 2006. Modellogi penelitian, Yogyakarta: Bina Aksara.

Asma, Nur. 2006. Model Pembelajaran Kooperatif. Jakarta: Departemen Pendidikan Nasional Direktorat Jenderal Pendidikan Tinggi Direktorat Ketenagaan

Astriany, N. 2012. Meningkatkan Hasil Belajar IPS Melalui Penggunaan Mind Mapping Siswa Kelas IV Sekolah Dasar Bekasi Utara. Jurnal Pendidikan Dasar

Dewiki dan Yuniati. 2006. Ilmu Alamiah Dasar. Jakarta : Universitas Terbuka di akses tanggal pada tanggal 26 juli 2017

Fathurrohman. 2007. Strategi Belajar Mengajar. Bandung : PT Refika Aditama

Ferdausy, Priharini. 2012. Peningkatan Kualitas Pembelajaran IPS melalui Model Role Playing dengan Media Video Pembelajaran pada Siswa Kelas III SD Negeri Petompon 01 Semarang. Skripsi, Jurusan Pendidikan Guru Sekolah Dasar Universitas Negeri Semarang.Hamalik, Oemar. 2011. Perencanaan Pengajaran berdasarkan Pendekatan Sistem. Jakarta: Bumi Aksara

Hamdani. 2011. Strategi Belajar Mengajar. Bandung: Pustaka Setia

Huda, Miftahul. 2013. Model-model Pengajaran dan Pembelajaran. Pustaka Pelajar. Malang

Jurnal Pendidikan Dasar, Vol 7, No.2, 2006: 74-83. Tersedia dalam http://dikdas.jurnal.unesa.ac.id/bank/jurnal/Penerapan_Pendekatan_Cooperativ

e_Learning_Model_Group_Investigation_Untuk_Meningkatkan_Pemahaman_

Siswa_Kelas_III_SLTP_8_Jember_Tentang_Volume_Tabung.pdf diakses pada tanggal 29 Juli 2013 pukul 9.34

Kusnandar. 2010. Guru Profesional Implementasi kurikulum Tingkat satuan Pendidikan (KTSP) dan Sukses Dalam Sertifikasi Guru. Jakarta: Rajawali Pers.

Peraturan Menteri Pendidikan Nasional Nomor 22 Tahun 2006.

Prastowo, Andi. 2012. Panduan Kreatif Membuat Bahan Ajar Inovatif. Jogjakarta: Diva Press

Pusat Pembinaan dan Departemen Pendidikan Nasional. (2001). Kamus Besar Bahasa Indonesia. Jakarta: Balai Pustaka. 
Bruce Joyce, Marsha Weil, dan Emily Calhoun (2009).Model Pembelajaran Examples Non Examples.Diunduh di:

http://ras-eko.blogspot.com/2011/05/ model pembelajaran example non example. html (8 maret 2014 pukul 20.34 WIB).

Riawati, Beti. 2012. Model Pembelajaran Group Investigation. Tersedia dalam http://10310258.blogspot.com/2012/01/model-pembelajaran-group-investigation.html diakses pada tanggal 30 Juli 2013 pukul 23.44

Rustaman, Nuryani, dkk. 2011. Materi dan Pembelajaran IPS SD. Jakarta: Universitas Terbuka

Sukiman. 2012. Pengembangan Media Pembelajaran. Yogyakarta: Pedagogia

Sunarto. 2012. Pengertian Hasil Belajar. Fasilitator idola (online). Tersedia: http//.sunartombs.wordpress.com. diakses 12 Juni 2017 (10.00).

Trianto. 2010. Mendesain Model Pembelajaran Inofativ-Progresif. Jakarta: PT. Kencana.

Trianto. 2011. Mendesain Model Pembelajaran Inovatif-Progresif. Jakarta: Kencana Prenada Media Group 